\title{
UTILIZING OF 1-HEXYL-1-METHYL-PYRROLIDINIUM BIS (TRIFLUOROMETHYL-SULFONYL) IMIDE AS MEDIUM FOR ELECTROCHEMICAL GENERATION OF SUPEROXIDE ION-RADICAL
}

\author{
MaAn HaYyan ${ }^{1,2}$, FarouQ S. MJalli ${ }^{1,3}$, Mohd Ali Hashim ${ }^{1,2}$ \\ AND INAS M. ALNASHEF ${ }^{4}$ \\ ${ }^{1}$ University of Malaya Centre for Ionic Liquids (UMCiL), \\ University of Malaya, 50603 Kuala Lumpur, Malaysia. \\ ${ }^{2}$ Department of Chemical Engineering, University of Malaya, \\ 50603 Kuala Lumpur, Malaysia \\ ${ }^{3}$ Petroleum \& Chemical Engineering Department, \\ Sultan Qaboos University, Muscat 123, Oman \\ ${ }^{4}$ Chemical Engineering Department, King Saud University, Riyadh, Saudi Arabia. \\ maan_hayyan@yahoo.com
}

\begin{abstract}
The superoxide ion-radical was generated and analysed electrochemically using cyclic voltammetry $(\mathrm{CV})$ technique from oxygen dissolved in a room-temperature ionic liquid, 1-hexyl-1-methyl-pyrrolidinium bis (trifluoromethylsulfonyl) imide, at atmospheric pressure. It was found that the generated superoxide ion was stable which indicates its possible use for further useful applications.
\end{abstract}

ABSTRAK: Ion radikal superoksida dihasil dan dianalisa secara elektrokimia menggunakan teknik voltammetri berkitar (cyclic voltammetry $(C V)$ ) daripada oksigen yang dilarutkan dalam larutan ionik pada suhu bilik, 1-hexyl-1-methyl-pyrrolidinium bis (trifluoromethylsulfonyl) imida, pada tekanan atmosfera. Didapati bahawa ion superoksida yang terhasil adalah stabil. Ini menunjukkan ia berkemungkinan berguna dalam aplikasi lain.

KEYWORDS: superoxide ion; ionic liquid; cyclic voltammetry; pyrrolidinium

\section{INTRODUCTION}

Ionic liquids are finding widespread use as alternative for conventional solvents in a variety of applications, including liquid-liquid extraction, fuel and solar cells, organometallic synthesis, electrochemical devices, capacitors, lubricants, stationary phases for chromatography; matrices for mass spectrometry, supports for the immobilization of enzymes, in separation technologies, as liquid crystals, templates for synthesis nanomaterials and materials for tissue preservation, in preparation of polymer-gel catalytic membranes, biphasic catalysis, and in generation of high conductivity materials. They have unique properties such as high electrical conductivity, wide temperature range of the liquid state, thermal stability, and low volatility. Moreover, because of their intrinsic conductivity and wide electrochemical windows, they have been utilized in a wide range of electrochemical applications [1-8]. One of these important applications is utilizing ILs as alternative media for the reduction of $\mathrm{O}_{2}$ into superoxide ion-radical $\left(\mathrm{O}_{2}{ }^{-}\right)$[9-14].

AlNashef et al. is the first team who has reported the evidence of the electrochemical generation of stable $\mathrm{O}_{2}{ }^{-}$in the ionic liquid, [BMIM] $\left[\mathrm{PF}_{6}\right.$ ] [10-11]. Subsequently, other ILs 
have been investigated comprising different structures of cations and anions such as trifluoromethylsulfonyl imide, tetrafluoroborate, hexafluorophosphate and chloroaluminate, combining with imidazolium, phsphnium or ammonium cations [9-17].

\section{EXPERIMENTAL AND MATERIALS}

Scheme 1 shows the structures of the cation and anion that make up the IL 1-hexyl-1methyl-pyrrolidinium bis (trifluoromethylsulfonyl) imide, [HMPyrr][N(Tf) 2 , (for synthesis, MERCK) which selected for this study. The molecular weight is $452.44 \mathrm{~g} / \mathrm{mol}$, and the formula is $\left(\mathrm{C}_{13} \mathrm{H}_{24} \mathrm{~F}_{6} \mathrm{~N}_{2} \mathrm{O}_{4} \mathrm{~S}_{2}\right)$.

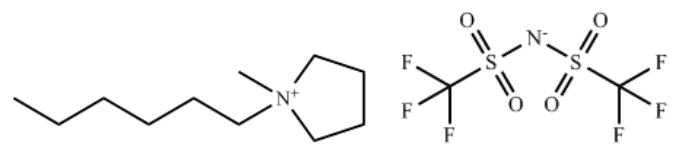

Scheme 1: The structure of [HMPyrr][N(Tf $\left.)_{2}\right]$.

Cyclic voltammetry $(\mathrm{CV})$ tests were performed in [HMPyrr][N(Tf $\left.)_{2}\right]$. The IL was dried overnight in a vacuum oven at $50{ }^{\circ} \mathrm{C}$. The electrochemistry was performed using potentiostat/galvanostat controlled by computer and data acquisition software. CVs can be conducted in a one compartment cell since the time of the experiment is relatively small to affect the ILs.

Glassy carbon electrode ( $3 \mathrm{~mm}$ diameter) was used as working electrode, and platinum electrode was used as a counter electrode, while $\mathrm{Ag} / \mathrm{AgCl}$ electrode was used as a reference electrode. All experiments were performed in a dry glove box under either an argon or helium atmosphere. Prior to superoxide ion-radical generation, a nitrogen sparge was used while obtaining a background voltammogram. Oxygen was then bubbled through the system for at least 30 minutes to allow sufficient solubilization. Between consecutive $\mathrm{CV}$ runs, oxygen was bubbled briefly to refresh the system with oxygen and to remove any concentration gradients. Nitrogen or oxygen sparging must be discontinued during the $\mathrm{CV}$ data acquisition.

\section{RESULTS AND DISCUSSION}

The electrochemical window (Fig. 1), shows a wide potential range which indicates the feasibility of use this IL for many electrochemical applications, one of them is electrochemical generation of $\mathrm{O}_{2}{ }^{--}$, due to its stability at $\pm(-1) \mathrm{V}$ the generation of $\mathrm{O}_{2}{ }^{\bullet-}$ occurs by reduction of $\mathrm{O}_{2}$. Figure 1 illustrates that the potential range is about $5.67 \mathrm{~V}$, this is can be attributed to the existence of pyrrolidinium cation and trifluoromethylsulfonyl anion, since this type of IL proves its wide electrochemical window [18].

Figure 2 shows the cyclic voltammograms for the one-electron reduction of $\mathrm{O}_{2}$ to $\mathrm{O}_{2}{ }^{\bullet-}$ - The reduction peak was found to be within (-1 to $-1.4 \mathrm{~V}$ ), Table 1, from $9 \mathrm{mV} / \mathrm{s}$ till 144 $\mathrm{mV} / \mathrm{s}$. The presence of the backward peak (oxidation peak) confirms that the generated superoxide is stable. The negligible background $\mathrm{CV}$ in the presence of nitrogen indicates that the IL is electrochemically stable in this range of potential $(0$ to $-1.5 \mathrm{~V})$. It can be stated in Fig 2 the difference between the reduction and oxidation peaks changed with scan rate. This indicates that the electrochemical generation of the superoxide ion in the studied ILs is not reversible. This is consistent with the electrochemistry of a kinetically irreversible soluble redox couple [19]. 


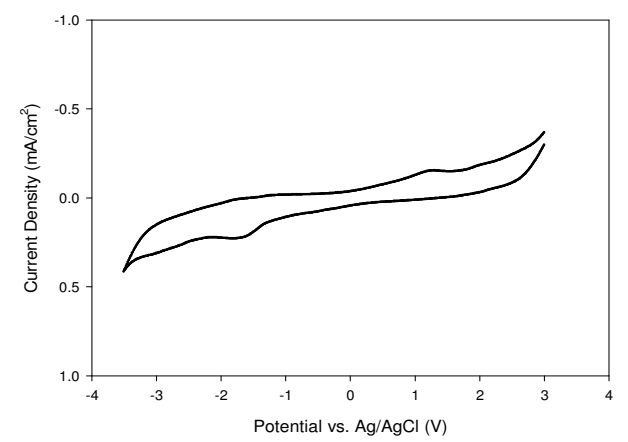

Fig. 1: Electrochemical window of $[\mathrm{HMPyrr}]\left[\mathrm{N}(\mathrm{Tf})_{2}\right]$.

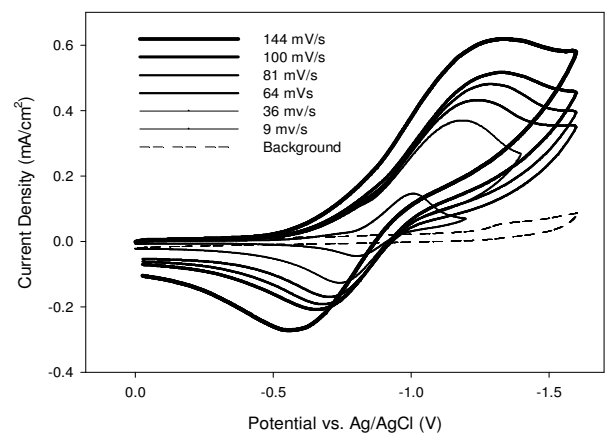

Fig. 2: CVs for various scan rates $(\mathrm{mV} / \mathrm{s})$ with oxygen and nitrogen (background) in $[\mathrm{HMPyrr}]\left[\mathrm{N}(\mathrm{Tf})_{2}\right]$.

Table 1: The current and Potential of reduction peak in CVs.

\begin{tabular}{ccc}
\hline $\begin{array}{c}\text { Scan Rate } \\
(\mathrm{mV} / \mathrm{s})\end{array}$ & $\begin{array}{c}\text { Current Peak } \\
(\mathrm{A}) \times 10^{-5}\end{array}$ & $\begin{array}{c}\text { Potential } \\
\text { Peak }(\mathrm{V})\end{array}$ \\
\hline 9 & 1.02 & -1.019 \\
36 & 2.60 & -1.207 \\
64 & 3.06 & -1.254 \\
81 & 3.40 & -1.308 \\
100 & 3.65 & -1.342 \\
144 & 4.38 & -1.426 \\
\hline
\end{tabular}

\section{CONCLUSION}

Stable superoxide ion-radical was generated in $[\mathrm{HMPyrr}]\left[\mathrm{N}(\mathrm{Tf})_{2}\right]$. Cyclic voltammetry technique was used to investigate the stability of $\mathrm{O}_{2}{ }^{\bullet-}$, the combined of pyrrolidinium cation with trifluoromethylsulfonyl anion were confirmed their capacity to be a good medium as ionic liquid for the electrochemical generation of $\mathrm{O}_{2}{ }^{\circ}$. 


\section{ACKNOWLEDGEMENT}

The authors thank the University of Malaya Centre for Ionic Liquids (UMCiL) for supporting this research and the National Plan for Science, Technology, and Innovation in King Saud University for their financial assistance through project no. 10-ENV1010-02.

\section{REFERENCES}

[1] T. Welton, Room temperature ionic liquids: Solvents for synthesis and catalysis, Chem. Rev. 99, 2071-2084, 1999.

[2] P. Wassersheid and T. Welton, "Ionic Liquids in Synthesis" Wiley-VCH, Weinheim, 2003.

[3] R. D. Rogers, M. Smiglak, A. Melten, "The Second Evolution of Ionic Liquids: From Solvents and Separations to Advanced Materials-Energetic Examples from the Ionic Liquid”. Accoun.Chem. Res. 40, 1182-1192, 2007.

[4] Z. Zhengxi, G. A. O. Xuhui, , Y. Li, "Electrochemical properties of room temperature ionic liquids incorporating $\mathrm{BF}_{4}{ }^{-}$and TFSI $^{-}$anions as green electrolytes". Chinese Science Bulletin 50, 18, 2005.

[5] F. Endres, D. MacFarlane, A. Abbott, "Electrodeposition from Ionic liquids", Wiley-VCH, 2008.

[6] S. O'Toole, S. Pentlavalli, A. P. Doherty, "Behavior of electrogenerated bases in roomtemperature ionic liquids". J. Phys. Chem. B, 111, pp. 9281-9287, 2007.

[7] D. S. Silvester, E. I. Rogers, L. E. Barrosse-Antle, T. L. Broder, R. G. Compton, "The electrochemistry of simple inorganic molecules in room temperature ionic liquids". Journal of the Brazilian Chemical Society 19, 611-620, 2008.

[8] M. C. Buzzeo, C. Hardacre, R. G. Compton, "Extended electrochemical windows made accessible by room temperature ionic liquid/organic solvent electrolyte systems". ChemPhysChem, 7, 176-180, 2006.

[9] M. T. Carter, C. L. Hussey, S. K. D. Strubinger, R. A. Osteryoung, "Electrochemical reduction of dioxygen in room-temperature imidazolium chloride-aluminum chloride molten salts", Inorg. Chem., 30, 1149, 1991.

[10] I. M. AlNashef, M. L. Leonard, M. C. Kittle, M. A. Matthews, J. W. Weidner, "Electrochemical Generation of Superoxide in Room-Temperature Ionic Liquids, Electrochem". Solid-State Lett. 4, D16, 2001.

[11] I. M. AlNashef , M. L. Leonard, M. C. Kittle, M. A. Matthews, J. W. Weidner, "Superoxide electrochemistry in an ionic liquid”, Ind. Eng. Chem. Res. 41, 4475, 2002.

[12] M. C. Buzzeo, O. V. Klymenko, J. D. Wadhawan, C. Hardacre, K. R. Seddon, and R. G. Compton, "Voltammetry of oxygen in the room-temperature ionic liquids 1-Ethyl-3methylimidazolium Bis ((trifluoromethyl) sulfonyl) imide and Hexyltriethylammonium Bis ((trifluoromethyl) sulfonyl) imide: One-electron reduction to form superoxide. steady-state and transient behavior in the same cyclic voltammogram resulting from widely different diffusion coefficients of oxygen and superoxide", J. Phys. Chem. A, 107, 8872, 2003.

[13] Y. Katayama, H. Onodera, M. Yamagata, and T. Miura, "Electrochemical reduction of oxygen in some hydrophobic room-temperature molten salt systems", J. Electrochem. Soc., 151, A59, 2004.

[14] R. G. Evans, O. V. Klymenko, S. A. Saddoughi, C. Hardacre, and R. G. Compton, "Electroreduction of oxygen in a series of room temperature ionic liquids composed of group 15-centered cations and anions". J. Phys. Chem. B, 108, 7878, 2004.

[15] M. C. Buzzeo, C. Hardacre, and R. C. Compton, "Kinetic analysis of the reaction between electrogenerated superoxide and carbon dioxide in the room temperature ionic liquids 1ethyl-3-methylimidazolium bis (trifluoromethylsulfonyl) imide and hexyltriethylammonium bis (trifluoromethylsulfonyl) imide”. Anal. Chem., 76, 45832004.

[16] D. Zhang, T. Okajima, F. Matsumoto, and T. Ohsaka, "Electroreduction of dioxygen in 1-nAlkyl-3-methylimidazolium tetrafluoroborate room-temperature ionic liquids". J. Electrochem. Soc., 151, D31, 2004. 
[17] M. M. Islam, T. Imase, T. Okajima, M. Takahashi, Y. Niikura, N. Kawashima, Y. Nakamura, and T. Ohsaka, "Stability of superoxide ion in imidazolium cation-based roomtemperature ionic liquids". J. Phys. Chem. A, 113, 912-916, 2009.

[18] Y. Katayama, K. Sekiguchi, M. Yamagata, and T. Miura, "Electrochemical behavior of oxygen/superoxide ion couple in 1-butyl-1-methylpyrrolidinium bis (trifluoromethylsulfonyl) imide room-temperature molten salt". J. Electrochem. Soc., 152, 8, E247-E250, 2005.

[19] A. J. Bard, L. R. Faulkner, "Electrochemical methods: fundamentals and applications", Wiley New York, 2001. 